\title{
Prevalence of antibodies to Brucella species in commercial raw bovine milk in Southwestern Uganda
}

\author{
Monicah Kamwine ${ }^{1}$, Patrick Orikiriza ${ }^{1,2}$, Kabanda Taseera', Jacob Stanley Iramiot ${ }^{3}$, Patrick Ojuka², Steven Ikiriza ${ }^{4}$, \\ Jeninah Atwebembeire', Duncan Otieno ${ }^{5}$, Silver Tweshengyereze ${ }^{5}$, Juliet Mwanga-Amumpaire ${ }^{1,2}$, Joel Bazira ${ }^{1 *^{*}}$ \\ and Yap Boum $11^{1,2^{*}}$
}

\begin{abstract}
Objectives: The purpose and objective of this research was to explore the prevalence of antibodies against Brucella species in raw milk samples collected in Southwestern Uganda, one of the biggest milk producing regions in the Country. We hypothesized that there is a high level of antibodies in milk samples from this region. This builds more evidence to other studies in the region on the level contamination of raw milk.
\end{abstract}

Results: A total of 185 raw milk samples, collected from dairy farms and factories in southwestern region, were tested for antibodies to Brucella spp. using the milk ring test (MRT) and indirect Enzyme-Linked Immunosorbent Assay (i-ELISA).We found a prevalence of $26.5 \%(49 / 185)$ by the two methods. This is related to previous reports in the region and adds more evidence on the need for further investigations to confirm the source of these antibodies and their relationship with disease in milk producing animals.

Keywords: Brucellosis, Diagnosis, Indirect ELISA, Milk ring test

\section{Background}

Brucellosis is a common disease in many cattle keeping countries communities consuming raw milk [1]. The disease is mainly zoonotically transmitted by species of $\mathrm{Bru}$ cella melitensis, Brucella abortus, Brucella suis, among others [2]. Although definitive isolation is the gold standard, it is time-consuming with low-sensitivity and requires biosafety level-3 making serological tests favorable in low resource settings [3].

The MRT is routinely used as a screening test on fresh but not pasteurized milk [4]. Despite its wide use, it is prone to false positive reactions especially in milk containing colostrum and at the end of lactation in cows with a hormonal disorder or mastitis [5]. Other screening tests

\footnotetext{
*Correspondence: jbazira@gmail.com; yap.boum@epicentre.msf.org ${ }^{1}$ Department of Microbiology, Mbarara University of Science and Technology, P.O. Box 1410, Mbarara, Uganda

2 Epicentre Mbarara Research Centre, P. O Box 1956, Mbarara, Uganda

Full list of author information is available at the end of the article
}

like i-ELISA are recommended along side MRT inorder to confirm presence of antibodies [6].

In Uganda, there is a high presence of cattle. The national demographic and health survey estimates that 14.5 and $23.2 \%$ of the urban and rural populations own local cattle [7]. It is also estimated that there is a total herd population of 14 million [8] producing about 1.9 billion liters of milk per year [9]. About $30 \%$ of this milk is consumed on the farm and may raise concern about zoonotic infections. The annual per capita consumption is estimated at 58 litres/person/annum [9]. Beyond East Africa, Uganda exported 6555 and 10,803 millions tons of milk in 2009 and 2011. In addition, 14,187 million tons of milk products were exported in 2011; 60\% of which were ultra heat treated $[9,10]$.

A recent study on farms in Southwestern Uganda estimated the prevalence of brucella antibodies at $29 \%$ using MRT alone [13]. There is limited data on the prevalence beyond the farm. In this study, we aimed to determine the prevalence of Brucella antibodies in southwestern region in order to guide the national disease control program. 


\section{Methods}

\section{Study location}

The study was carried out in greater Mbarara region, which is located in Southwestern Uganda.

The equatorial temperate climate includes two rainy seasons (March-May and September-December) with mean minimum temperature of $14.6{ }^{\circ} \mathrm{C}$ and maximum annual temperature of $30.8{ }^{\circ} \mathrm{C}$. The climate and annual rainfall of $822 \mathrm{~mm}$ occur in 114 rainy days in the year and is favorable for dairy production [11].

\section{Definition of dairies}

We considered only dairies where farmers were able to accumulate more than $500 \mathrm{l}$ of milk per day.

\section{Sample collections and handling}

Between August and September 2014 we performed a descriptive cross sectional serosurvey. A multi-stage sampling technique based on districts was adopted. We started by generating a list of possible farms and factories producing milk at the district. This was compiled with the assistance of District Dairy Development Authority (DDA) officials. The list comprised of dairies from four districts: Kiruhura, Mbarara, Bushenyi and Isingiro. These four were purposively selected because they are the main dairy producers according to DDA. In Kiruhura, Mbarara, Bushenyi and Isingiro, 96, 59, 18, and 12 dairies respectively were conveniently selected, taking into account their spatial distribution (Table 1). We started sampling from the diaries at the district and ended at the local council level. In all the cases, the districts had bigger collection points compared to the local council. From each dairy the owners were asked to consent to be part of the study. The consent process was done in private to avoid interference and also ensure confidentiality. Consenting participants were explained about the study and were given a right to withdraw at anytime if they felt uncomfortable. The consent form was translated in the local language (Runyankole). After consenting, we collected $10 \mathrm{ml}$ of raw milk from randomly selected coolers and kept all samples refrigerated at $4{ }^{\circ} \mathrm{C}$ prior to

Table 1 Prevalence of antibodies against Brucella spp. in raw milk samples by districts

\begin{tabular}{lllll}
\hline District & $\begin{array}{l}\text { No. of samples } \\
\text { examined }\end{array}$ & $\begin{array}{l}\text { No. of positive } \\
\text { samples }\end{array}$ & $\begin{array}{l}\text { Prevalence } \\
\text { (\%) }\end{array}$ & $\mathbf{9 5 \% ~ C l}$ \\
\hline Kiruhura & 96 & 39 & 40.6 & $30.7-51.1$ \\
Mbarara & 59 & 33 & 55.9 & $42.4-66.8$ \\
Bushenyi & 18 & 10 & 55.6 & $51.6-97.9$ \\
Isingiro & 12 & 8 & 66.7 & $44.4-97.4$ \\
Total & 185 & 90 & 48.6 & $41.2-56.1$ \\
\hline
\end{tabular}

laboratory investigations. These included a mixture of fresh to 2 days' old milk collected samples.

\section{Laboratory methods}

We processed the samples at Epicentre Mbarara Research Centre and Milk Research Laboratory, Mbarara University of Science and Technology. All specimens were tested with two methods: (1) the milk ring test (MRT) and (2) Indirect Enzyme-linked immune absorbent assays (i-ELISA). We performed the MRT as described previously [6]. In brief we added $30 \mu \mathrm{l}$ of B. abortus Bang Ring Antigen (State Biological Laboratory, Institute of Veterinary Preventive Medicine, Ranipet, India) to $1 \mathrm{ml}$ of raw milk that had been kept at $4{ }^{\circ} \mathrm{C}$ for $24 \mathrm{~h}$ at the Milk Research Laboratory. Samples were incubated for $1 \mathrm{~h}$ at $37^{\circ} \mathrm{C}$ together with positive and negative controls. Agglutinated Brucella cells were picked up by fat globules as they rose, forming a dark cream layer on top of the sample as previously described [6]. The reading was done and a positive reaction was indicated by a purple layer over a white column of milk [3]. A negative test was indicated when the color of the underlying milk was more blue than that of the cream layer.

I-ELISA was performed with the ID Screen ${ }^{\circledR}$ Brucellosis milk indirect assay (Innovative Diagnostics, Grabels, France). The assay detects antibodies against Brucella spp. in bovine, ovine and caprine milk. Detection of anti-Brucella antibodies was performed and interpreted according to manufacturer's instructions [12].

\section{Statistical analysis}

Data were entered into Microsoft Excel spreadsheets, and analyzed using Stata SE v12 software (College Station, Texas, USA). In this study, a serial testing protocol was used and therefore, a milk sample was considered positive for antibodies against Brucella spp. if it was positive for both the MRT and i-ELISA. We also compared the prevalence of antibodies against Brucella spp. between factories and farms, including individual milk coolers, milk bicycle carriers and the family's farms, using Chi square test. Finally, we measured the degree of agreement between MRT and i-ELISA using Kappa statistics.

\section{Results}

Between August and September 2014, we collected 185 raw milk samples from 185 dairies in Kiruhura, Mbarara, Bushenyi, and Isingiro districts of Southwestern Uganda. Among them, 51.9\% (96/185) were collected from Kiruhura district, 31.9\% (59/185) from Mbarara district, 9.7\% (18/185) from Bushenyi district, and 6.5\% (12/185) from Isingiro district (Table 1). Of these, 22 (11.9\%) were from factories and 163 (88.1\%) from farms (Table 2). 
Table 2 Prevalence of antibodies against Brucella spp. in raw milk samples between factories and farms

\begin{tabular}{llllll}
\hline $\begin{array}{l}\text { Collec- } \\
\text { tion sites }\end{array}$ & $\begin{array}{l}\text { Number } \\
\text { of samples } \\
\text { examined }\end{array}$ & $\begin{array}{l}\text { Number } \\
\text { of positive } \\
\text { samples }\end{array}$ & $\begin{array}{l}\text { Preva- } \\
\text { lence (\%) }\end{array}$ & $\mathbf{9 5 \% ~ C l}$ & $\begin{array}{l}\text { Chi } \\
\text { square, } \\
\text { p value }\end{array}$ \\
\hline Factories & 22 & 18 & 81.82 & $59.7-94.8$ & 0.004 \\
Farms & 163 & 72 & 44.17 & $36.4-52.1$ & \\
\hline
\end{tabular}

We found antibodies against Brucella spp. in 62 (33.5\%) raw milk samples using the milk ring test alone and 90 (49.45\%) with i-Elisa test (Table 3). However, the overall prevalence of antibodies against Brucella spp. was 26.5\% using both methods, on the same samples (Table 1). We found the highest proportion of antibodies in Bushenyi 44.4\%, [95\% confidence interval (CI) 21.5-69.2] and the lowest in Kiruhura 14.6\% (95\% CI 8.2-23.2). However basing on the confidence intervals, the difference was not statistically significant among Kiruhura, Mbarara, Bushenyi and Isingiro (Table 1). We found a significantly higher prevalence in samples collected at factories than those collected directly from farms, using Chi square test $(54.5 \%$ vs. $22.7 \%$, p value $=0.004$, Table 2$)$. We also found agreement between MRT and i-ELISA methods ( $\mathrm{\kappa} 0.40$, $\mathrm{p}<0.0001$ ) (Table 4).

\section{Discussion}

We detected antibodies to Brucella spp. at 62 (33.5\%) and 90 (49.45\%) using MRT and i-ELISA respectively in raw milk samples collected in the greatest milk producing areas of Southwestern Uganda. However, using a combination of the two screening methods, the antibodies were

Table 3 Prevalence of antibodies against Brucella spp. in raw milk using i-ELISA and MRT

\begin{tabular}{lllll}
\hline & Positive $\mathbf{n}(\%)$ & Negative $\mathbf{n}(\%)$ & Total & $\begin{array}{l}\text { Chi square, } \\
\text { p value }\end{array}$ \\
\hline MRT & $62(33.5)$ & $123(66.5)$ & 185 & $<0.001$ \\
i-ELISA & $90(49.5)$ & $92(50.5)$ & $182^{\text {a }}$ & \\
Total & 152 & 215 & 367 & \\
\hline
\end{tabular}

a 3 invalids (doubtful)

Table 4 Comparison between MRT and i-ELISA in detection of antibodies against Brucella spp.

\begin{tabular}{|c|c|c|c|c|}
\hline \multirow[b]{2}{*}{ MRT } & \multicolumn{4}{|l|}{ i-ELISA } \\
\hline & $\begin{array}{l}\text { Negative } \\
\text { n (\%) }\end{array}$ & $\begin{array}{l}\text { Positive } \\
\text { n (\%) }\end{array}$ & Total & $\begin{array}{l}\text { Chi square, } \\
\text { p value }\end{array}$ \\
\hline Negative (n) & $80(66.1)$ & 41 (33.9) & 121 & $<0.001$ \\
\hline Positive (n) & $12(19.7)$ & 49 (80.3) & 61 & \\
\hline Total & 92 & 90 & 182 & \\
\hline
\end{tabular}

confirmed in $26.5 \%$ of samples. We considered a combination of two screening methods in order to increase accuracy of detection, considering that each of these has it's limitations. Based on our findings, the antibody prevalence is generally comparable to what has been previously reported in this region. A recent study also found the level of antibodies at $29 \%$ in a rural part of Southwestern Uganda [13]. Our findings however differ from what was reported in central part of Uganda, with an equally high presence of cattle, where the level of antibodies was much lower at $1.2-3.3 \%$ but using i-ELISA alone [14]. This implies that there is relatively high prevalence of antibodies against Brucella spp. in raw milk in Southwestern Uganda. This is a potential risk considering that some cows could be harboring brucella pathogens and zoonotically infecting between themselves and humans.

Presence of antibodies in milk has been shown to project ongoing transmission. In one of the studies conducted in Uganda, presence of antibodies in human serum was strongly associated with a positive screening test on the milk samples from cattle of the farmer [13]. This therefore suggests that there is possibly a $26.5 \%$ chance of transmission. The population that consumes raw milk may be at increased risk of developing brucellosis [9]. Despite this assumption, further studies should look at the actual presence of brucella pathogens in the milk using molecular and cultural methods inorder to ascertain the extent of risk.

Although we didn't find geographic differences we observed a difference among the collection sites. We observed a higher prevalence in milk collected from factories compared to farms. This could be explained by the fact that factories were purchasing the entire milk produced by selected farms and thus the high volumes could have contributed to this difference. Since the milk was collected at the factory before treatment, we believe that local farmers may have been biased by expected pasteurization process at the factory. Thus they were less likely to get concerned about the hygiene and conservation of milk before sending it. We also noted a higher percentage of antibodies in raw milk collected from Bushenyi although the proportion was not statistically significant.

Though we have not collected processed milk from these factories, we believe that the use of the pasteurization process, which is commonly performed at milk factories will reduce the risk of brucellosis in the population. There is evidence that pasteurization at a temperature of $62-63{ }^{\circ} \mathrm{C}$ applied $3 \mathrm{~min}$ is sufficient to destroy Brucella organisms [15].

Basing on single test, the prevalence of antibodies in milk would be overestimated. The MRT and i-ELISA estimated the rate at $62(33.5 \%)$ and $90(49.45 \%)$ respectively. Using a single test, high prevalence of antibodies in raw 
milk has been reported in some countries in East African region. In Tanzania, the rate was found at $56 \%$ in samples tested using MRT [16]. This figure could be an overestimation considering that only one method was used. Nevertheless, the high antibodies may be explained by the fact that about $90 \%$ of milk sales in Tanzania are in the hands of farmers who are known to harbour beliefs that milk is inherently hygienic [16]. However, in urban setting where milk is pasteurized and/or boiled before drinking, a lower prevalence of bovine brucellosis from milk has been reported. For example in Kampala, the capital city of Uganda, where antibody prevalence of $12.6 \%$ has been reported from marketed milk using the i-ELISA assay [17]. In contrast, in Kenya where standard pasteurization techniques are adopted [18], Kang'ethe et al. reported a proportion of $1 \%$ showing the impact of pasteurization on the antibody presence in raw milk samples [18].

We also found a significant difference in detection of antibodies against Brucella spp. between the MRT and i-ELISA assays; $\mathrm{k}$ agreement of $0.40, \mathrm{p}<0.0001$. While the sensitivity and specificity of MRT have been described at 85 and $95 \%$ respectively [19], the reported performance of i-ELISA for detection of antibodies against Brucella spp. in milk were much higher (sensitivity $98.5 \%$, specificity $99.5 \%)[20,21]$. This highlights the importance of the two methods since a single test may under or over report the burden of the disease. Fortunately, presence of antibodies against Brucella spp. does not always reflect presence of Brucella pathogens. In one of the studies, ELISA detected antibodies in $21.4 \%$ of the milk samples, but only $7 \%$ was confirmed by PCR [22]. For that reason, confirmation of positive screening tests remains critical although most facilities continue to rely on single test results.

Nevertheless, the discrepancy encountered in this study using the two methods is comparable with studies performed in Sudan [19]. Therefore there is need for further studies to investigate field performance of MRT in low resources setting where there is high production and consumption of raw milk.

\section{Conclusion}

We observed a high prevalence of antibodies against Brucella spp. in raw milk collected from dairies in Southwestern Uganda, the biggest producers of milk in the country. These findings need further confirmation by molecular and culture methods since presence of antibodies may not always indicate disease. This is important considering that raw milk consumption on the farm is a common practice in Uganda especially in rural settings. This will help public health experts to focus interventions appropriately.

\section{Limitations}

- We were unable to confirm the discordant results between MRT and i-ELISA methods.

- We could not rule out possible contaminating organisms that may cause cross reactions, for example, bacteria causing mastitis in the milk samples.

- We were unable to confirm presence of pathogenic Brucella spp. in milk samples through culture or PCR based methods.

- The sample size from districts was small to make a generalizable conclusion.

\section{Abbreviations}

ELISA: Enzyme Linked Immunosorbent Assay; MRT: milk ring test; WHO: World Health Organization; DDA: dairy drug authority.

\section{Authors' contributions}

MK designed the study and collected data with support from $\mathrm{PO}$ and $\mathrm{YB}$. $\mathrm{PO}$ $K T$, JB, YB, MK, PO JSI, SI, JA, DO, ST, processed samples, interpretated results, performed analysis and wrote the manuscript. All authors read and approved the final manuscript.

\section{Author details}

${ }^{1}$ Department of Microbiology, Mbarara University of Science and Technology, P.O. Box 1410, Mbarara, Uganda. ${ }^{2}$ Epicentre Mbarara Research Centre, P. O Box 1956, Mbarara, Uganda. ${ }^{3}$ Department of Microbiology, Busitema University, Busitema, Uganda. ${ }^{4}$ Dairy Development Authority, Kampala, Uganda. ${ }^{5}$ GBK Group of Companies, Mbarara, Uganda.

\section{Acknowledgements}

We thank Epicentre Mbarara Research Centre for allowing us to use their equipment in the laboratory. We are strongly indebted to Dairy Development Authority Mbarara branch and GBK group of companies for helping in sample collection. We are grateful to Mark Seidner for his critical review of the manuscript.

\section{Competing interests}

The authors declare that they have no competing interests.

\section{Availability of data and materials}

The dataset used and/or analysed during this study is available from the corresponding author on reasonable request.

Consent to publish

All authors have consent to the publication of the manuscript.

\section{Ethics approval and consent to participate}

The study was approved by the Research and Ethics Committee of Mbarara University of Science and Technology (04/01-14). The participants gave written informed consent

\section{Funding}

The entire funding was obtained through Uganda Research Student Support Fund (URSSF), an initiative that was conceived to fund global students' researches and link programs between Ugandan Universities and several international partners to conduct research on global health issues. The funders had no role in study design, data collection and analysis, decision to publish, or preparation of the manuscript.

\section{Publisher's Note}

Springer Nature remains neutral with regard to jurisdictional claims in published maps and institutional affiliations.

Received: 26 August 2015 Accepted: 6 June 2017

Published online: 08 September 2017 


\section{References}

1. FAO. Brucellosis in humans and animals. WHO Library Cataloguing-inPublication Data. Geneva, Switzerland. 2006.WHO/CDS/EPR/2006.7.

2. Mugizi RD, Muradrasoli S, Boqvist S, Erume J, Nasinyama GW, Waiswa C, Mboowa G, Klint M, Magnusson U. Isolation and molecular characterization of brucella isolates in cattle milk in Uganda. BioMed Res Int 2015:2015(720413):9.

3. Poester PF, Nielsen K, Samartino EL, Yu LW. Diagnosis of brucellosis. Open Vet Sci J. 2010:2010(4):46-60.

4. Fleischmann. Broadside. 1937; 12:AA 251439

5. Morgan WJP. The serological diagnosis of bovine brucellosis. Vet Rec. 1967;80:612-21.

6. Najibullah M, Lakshmanasami G, Bharathy S, Kannan P. Milk Ring Test for spot identification of Brucella abortus infection in single cow herds. J Adv Vet Anim Res. 2014;1(2):70-2.

7. Uganda National Demographic Health Survey. Uganda Bureau of statistics. Kampala Uganda: UBOS and Calverton, Maryland: ICF International Inc.; 2011.

8. Okwenye A. Rehabilitation of the dairy industry in Uganda. Dairy Development Authority (DDA). Report 2014.

9. Sikawa GY and Mugisha J. Factors influencing South-Western Uganda dairy farmers' choice of the milk marketing channel: a case study of Kiruhura District South-Western Uganda. Research Report series. 2011; 1:0856-9681

10. Grimaud P, Mpairwe D, Chalimbaud J, Messad S, Faye B. The place of Sanga cattle in dairy production in Uganda. Trop Anim Health Prod. 2007:39(3):217-27

11. Faye B, Castel V, Lesnoff M, Rutabinda D, Dhalwa J. Tuberculosis and brucellosis prevalence survey on dairy cattle in Mbarara milk basin (Uganda). Prev Vet Med. 2005;1567(4):267-81.

12. World Organization for Animal Health. Manual of diagnostic tests and vaccines for terrestrial animals. Paris: OlE; 2012
15. Miller R, Nakavuma JL, Ssajjakambwe P, Vudriko P, Musisi N, Kaneene JB. The prevalence of brucellosis in cattle, goats and humans in rural Uganda: a comparative study. Transbound Emerg Dis. 2016;63(6):e197-210.

14. Nizeyimana G, Mwiine NF, Ayebazibwe C. Comparative Brucella abortus antibody prevalence in cattle under contrasting husbandry practices in Uganda. J S Afr Vet Assoc. 2013:84(1):5.

15. Murray C, McNutt SH, Purwin P. The effect of pasteurization upon Brucella Melitensis var. suis. J Dairy Sci. 1932;15(1):6-13.

16. Swai and Schoonman. Microbial quality and associated health risks of raw milk marketed in the Tanga region of Tanzania. Asian Pac J Trop Biomed. 2011;1(3):217-22

17. Makita K, Fevre ME, Waiswa C, Eisler MC, Welburn SC. How human brucellosis incidence in urban Kampala can be reduced most efficiently? A stochastic risk assessment of informally-marketed milk. PLOS ONE. 2010:5(12):e14188.

18. Kang'ethe EK, Ekuttan CE, Kimani VN, Kiragu MW. Investigation into the prevalence of bovine brucellosis and the risk factors that predispose humans to infection among urban dairy and non-dairy farming households in Dagoretti Division, Nairobi, Kenya. East Afr Med J. 2007;84(11 Suppl):S96-100

19. Salman AMA, Hind A, Nasri El. Evaluation of four serological tests to detect prevalence of bovine brucellosis in Khartoum state. J Cell Anim Biol. 2012;6(9):140-3.

20. Nielsen K, Kelly L, Gall D, Nicoletti P, Kelly W. Improved competitive enzyme immunoassay for the diagnosis of bovine brucellosis. Vet Immunol Immunopathol. 1995:46(3-4):285-91.

21. Bosnakovski J, Mitrov D, Naletoski I. Diagnostic validation of ovine and caprine brucellosis using serum and milk elisa. Prilozi. 2010;31(1):103-15.

22. Terzý G, Büyüktanir O, Genç O, Gücükoðlu A, Yurdusev N. Detection of brucella antibody and DNA in cow milk by ELISA and PCR methods. Kafkas Üniv Vet Fak Derg. 2010;16(Suppl-A):S47-52.

\section{Submit your next manuscript to BioMed Central and we will help you at every step:}

- We accept pre-submission inquiries

- Our selector tool helps you to find the most relevant journal

- We provide round the clock customer support

- Convenient online submission

- Thorough peer review

- Inclusion in PubMed and all major indexing services

- Maximum visibility for your research

Submit your manuscript at www.biomedcentral.com/submit
() BioMed Central 